Article

\title{
Two New Pentacyclic Triterpene Saponins from the Leaves of Akebia trifoliata
}

\author{
Qiao-Lin $\mathrm{Xu}^{1,+}{ }^{1}$, Jing Wang ${ }^{2,3, \dagger}$, Li-Mei Dong ${ }^{2,4}$, Qiang Zhang ${ }^{3,4}$, Bi Luo ${ }^{3,4}$, Yong-Xia Jia ${ }^{2,3}$, \\ Hong-Feng Wang ${ }^{1}$ and Jian-Wen Tan ${ }^{2,3, *}$ \\ 1 Guangdong Provincial Key Laboratory of Bio-Control for Forest Diseases and Pests, Guangdong Academy \\ of Forestry, Guangzhou 510520, China; qlxu@sinogaf.cn (Q.-L.X.); wanghf@sinogaf.cn (H.-F.W.) \\ 2 Key Laboratory of Plant Resources Conservation and Sustainable Utilization, South China Botanical Garden, \\ Chinese Academy of Sciences, Guangzhou 510650, China; w_j771@163.com (J.W.); \\ donglimei1990@163.com (L.-M.D.); jyx@scib.ac.cn (Y.-X.J.) \\ 3 Guangdong Provincial Key Laboratory of Applied Botany, South China Botanical Garden, Chinese Academy \\ of Sciences, Guangzhou 510650, China; zqiang55@126.com (Q.Z.); bluo023@163.com (B.L.) \\ 4 College of Life Sciences, University of Chinese Academy of Sciences, Beijing 100049, China \\ * Correspondence: jwtan@scbg.ac.cn; Tel./Fax: +86-20-3708-2054 \\ + These authors contributed equally to this work.
}

Academic Editor: Derek J. McPhees

Received: 28 June 2016; Accepted: 19 July 2016; Published: 22 July 2016

\begin{abstract}
Two new pentacyclic triterpene saponins, named akebiaoside K (1) and akebiaoside $\mathrm{N}$ (2), were isolated from the leaves of Akebia trifoliata, together with five known triterpenoids 3-7. They were all isolated from the leaves of $A$. trifoliata for the first time. Their structures were established by spectral and chemical means. Triterpenes 5 and 7 were found to show moderate in vitro cytotoxicity against human tumor A549, HeLa and HepG2 cell lines, with $\mathrm{IC}_{50}$ values ranging from 0.023 to $0.038 \mathrm{mM}$. Triterpenes $5-7$ were further revealed to show significant in vitro $\alpha$-glucosidase inhibitory activity with $\mathrm{IC}_{50}$ values from 0.040 to $0.220 \mathrm{mM}$, making them more potent than the reference compound acarbose $\left(\mathrm{IC}_{50} 0.409 \mathrm{mM}\right.$ ). Meanwhile, no obvious inhibitory effects were observed for the isolated triterpene saponins $\mathbf{1 - 4}$ in both bioactivity assays.
\end{abstract}

Keywords: Akebia trifoliata; triterpene saponins; $\alpha$-glucosidase inhibitor; cytotoxicity

\section{Introduction}

Akebia trifoliata (Thunb.) Koidz. is a perennial, woody liana mainly distributed in the eastern part of Asia [1]. Its fresh fruit, commonly called 'Ba-Yue-Gua' in China, has long been consumed by the local people as a delicious food [2]. The air-dried stems and fruits of A. trifoliata have traditionally been used in China for centuries as an antiphlogistic, antineoplastic and diuretic agent $[3,4]$. To date, phytochemical studies have revealed structurally diverse triterpenes, triterpene saponins, phenolics and lignans from this plant, and some of them displayed significant biological activities [5-10]. However, those studies were mainly concentrated on the stems and fruits, and seldom focused on the leaves, though our thin layer chromatography (TLC) examination of the ethanol extract showed that it was highly possible that the leaves of $A$. trifoliata could also be a promising source of functional natural products. To examine those potential uncharacterized chemicals in the leaves of A. trifoliata, a phytochemical investigation on this plant part was carried out, whereby seven pentacyclic triterpenoids 1-7, including two new triterpene saponins (compounds 1 and 2) were obtained (Figure 1). Herein, the isolation and structure elucidation of these compounds are described. Besides, compounds 1-7 were also tested for their $\alpha$-glucosidase inhibitory activity and their cytotoxic activity against three human tumor cell lines. 

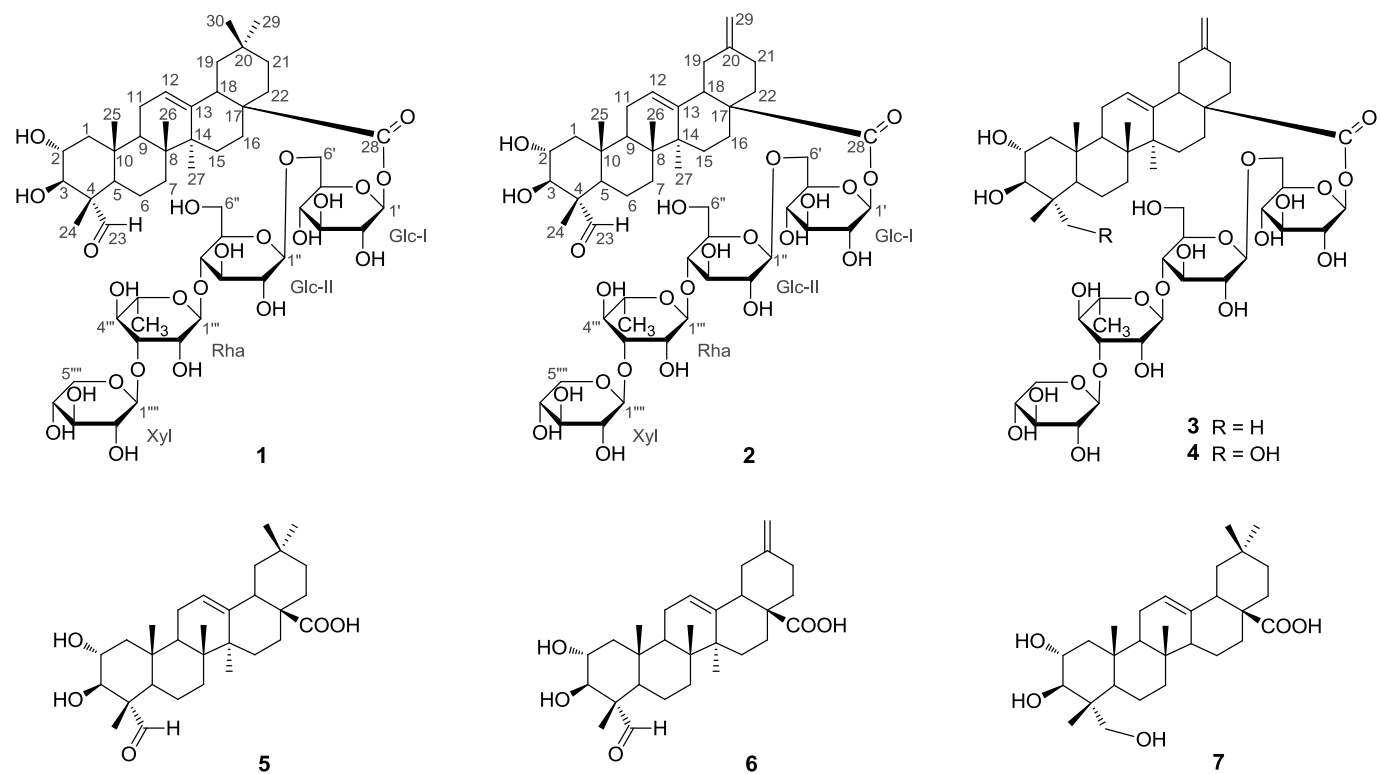

Figure 1. Chemical structures of compounds 1-7.

\section{Results and Discussion}

Compound 1 was obtained as a white, amorphous powder. Its (-)- and (+)-ESI-MS displayed quasi-molecular ion peaks at $m / z 1087[\mathrm{M}-\mathrm{H}]^{-}$and $1111[\mathrm{M}+\mathrm{Na}]^{+}$, respectively, corresponding to the molecular formula of $\mathrm{C}_{53} \mathrm{H}_{84} \mathrm{O}_{23}$, which was confirmed by further HR-ESI-MS (+) analysis $\left([\mathrm{M}+\mathrm{Na}]^{+} m / z\right.$ 1111.5297, calcd. 1111.5296). The ${ }^{1} \mathrm{H}$ - and ${ }^{13} \mathrm{C}-\mathrm{NMR}$ spectra of $\mathbf{1}$ exhibited four sugar anomeric protons at $\delta_{\mathrm{H}} 6.22$ (Glc-I-1), 4.95 (Glc-II-1), 5.87 (Rha-1), and 5.24 (Xyl-1) (Table 1), and anomeric carbons at $\delta_{C} 95.5,104.7,102.2$ and 107.1 (Table 2), suggesting the existence of four sugar moieties in the molecule. Acid hydrolysis of 1 with $2 \mathrm{~N} \mathrm{HCl}$ afforded D-glucose, L-rhamnose and D-xylose in the ratio of 2:1:1, which were identified by GC-MS analysis of their chiral derivatives (see experimental part). The ${ }^{1} \mathrm{H}$ - and ${ }^{13} \mathrm{C}$-NMR assignments (Tables 1 and 2) of the sugar moieties in $\mathbf{1}$ were established by interpretation of combined HSQC and HMBC data (See the Supplementary Materials). After having excluded the resonances due to the sugar moieties, the remaining signals in the ${ }^{1} \mathrm{H}-\mathrm{NMR}$ spectrum for the aglycone unit of 1 were readily recognized for six tertiary methyls at $\delta_{\mathrm{H}} 1.42(3 \mathrm{H}, \mathrm{s})$, $1.20(3 \mathrm{H}, \mathrm{s}), 1.07(3 \mathrm{H}, \mathrm{s}), 1.04(3 \mathrm{H}, \mathrm{s}), 0.90(3 \mathrm{H}, \mathrm{s})$ and $0.88(3 \mathrm{H}, \mathrm{s})$, an olefinic proton at $\delta_{\mathrm{H}} 5.40(1 \mathrm{H}, \mathrm{t})$, two oxymethine protons at $\delta_{\mathrm{H}} 4.21(1 \mathrm{H}, \mathrm{m})$ and $4.04(1 \mathrm{H}, \mathrm{d}, J=10.1 \mathrm{~Hz})$, and an aldehyde proton at $\delta_{\mathrm{H}} 9.61(1 \mathrm{H}, \mathrm{s})$. The ${ }^{13} \mathrm{C}-\mathrm{NMR}$ spectrum indicated, besides the signals for the sugar moieties, 30 carbons for the aglycone unit, including six methyls, nine methylenes, six methines (including an olefinic methine at $\delta_{C} 122.4$, two oxygenated methines at $\delta_{C} 67.9$ and 76.9 and an aldehyde carbon at $\delta_{C} 206.3$ ), and nine quaternary carbons (including an olefinic carbon at $\delta_{C} 144.0$ and a carbonyl carbon at $\delta_{C} 176.3$ ). By comparison, it was found that the ${ }^{1} \mathrm{H}$ - and ${ }^{13} \mathrm{C}-\mathrm{NMR}$ spectroscopic data (Tables 1 and 2) of the aglycone of 1 were closely related to those of $2 \alpha, 3 \beta$-dihydroxy-23-oxo-olean-12-en-28-oic acid [11], a known triterpene which was also obtained in this study as 5 , with the major difference of the chemical shift value of the carboxyl group at C-28 was shifted from $\delta_{C} 180.0$ in 5 to $\delta_{C} 176.3$ in $\mathbf{1}$. These findings supported the fact that $\mathbf{1}$, as shown in Figure 1, was a monodesmoside saponin of $\mathbf{5}$ with an oligosaccharide chain linked at C-28 [12]. This deduction was consistent with the molecular formula of 1 , and further in complete accordance with the 2D NMR spectroscopic data. In the HMBC spectrum, ${ }^{1} \mathrm{H}-{ }^{13} \mathrm{C}$ long-range correlation of $\mathrm{H}-1^{\prime}\left(\delta_{\mathrm{H}} 6.22\right)$ with $\mathrm{C}-28\left(\delta_{\mathrm{C}} 176.3\right)$ was exhibited, which evidenced the glycoside linkage of Glc-I at C-1' with the aglycone at C-28. The observation of HMBC correlations of H-1" $\left(\delta_{\mathrm{H}} 4.95\right)$ with C-6 $6^{\prime}\left(\delta_{\mathrm{C}} 69.0\right)$, of H-1"' $\left(\delta_{\mathrm{H}} 5.87\right)$ with C-5" $\left(\delta_{\mathrm{C}} 77.0\right)$, and of H-1"' $\left(\delta_{\mathrm{H}} 5.24\right)$ with $C-3^{\prime \prime \prime}\left(\delta_{C} 83.0\right)$ confirmed the sugar sequence as shown in Figure 2 . The $\beta$-anomeric configuration of 
the D-glucose (Glc-I and Glc-II) and the xylose (Xyl) moieties were determined on the basis of their coupling constants of ${ }^{3} J_{\mathrm{H} 1^{\prime}, \mathrm{H} 2^{\prime}}(8.1 \mathrm{~Hz}),{ }^{3} J_{\mathrm{H} 1^{\prime \prime}, \mathrm{H} 2^{\prime \prime}}(7.8 \mathrm{~Hz})$ and ${ }^{3} J_{\mathrm{H} 1^{\prime \prime \prime}, \mathrm{H} 2^{\prime \prime \prime \prime}}(7.5 \mathrm{~Hz})$, respectively [12,13].

Table 1. The ${ }^{1} \mathrm{H}-\mathrm{NMR}(500 \mathrm{MHz})$ spectral data ((ppm), J in $\left.\mathrm{Hz}\right)$ of $\mathbf{1}$ and 2.

\begin{tabular}{|c|c|c|c|c|c|}
\hline No. & $\delta_{H}(1)^{a}$ & $\delta_{H}(2) b$ & No. & $\delta_{H}(1)^{a}$ & $\delta_{H}(2){ }^{b}$ \\
\hline 1 & $2.28(\mathrm{~m}), 1.38(\mathrm{~m})$ & $2.25(\mathrm{~m}), 1.35(\mathrm{~m})$ & $1^{\prime}$ & $6.22 \mathrm{~d}(8.1)$ & $6.14 \mathrm{~d}(8.2)$ \\
\hline 2 & $4.21(\mathrm{~m})$ & $4.20(\mathrm{~m})$ & $2^{\prime}$ & $4.11(\mathrm{~m})$ & $4.08(\mathrm{~m})$ \\
\hline 3 & $4.04(\mathrm{~d}, 10.1)$ & $4.00(\mathrm{~d}, 9.3)$ & $3^{\prime}$ & $4.21(\mathrm{~m})$ & $4.18(\mathrm{~m})$ \\
\hline 5 & $1.60(\mathrm{~m})$ & $1.56(\mathrm{~m})$ & $4^{\prime}$ & $4.31(\mathrm{~m})$ & $4.31(\mathrm{~m})$ \\
\hline 6 & $1.46(\mathrm{~m}), 1.01(\mathrm{~m})$ & $1.43(\mathrm{~m}), 0.97(\mathrm{~m})$ & $5^{\prime}$ & $4.07(\mathrm{~m})$ & $4.15(\mathrm{~m})$ \\
\hline 7 & $1.46(\mathrm{~m}), 1.21(\mathrm{~m})$ & $1.80(\mathrm{~m}), 1.67(\mathrm{~m})$ & $6^{\prime}$ & $4.65(10.5), 4.27(\mathrm{~m})$ & $4.61(\mathrm{~m}), 4.27(\mathrm{~m})$ \\
\hline 9 & $1.86(\mathrm{~m})$ & $1.79(\mathrm{~m})$ & $1^{\prime \prime}$ & $4.95(\mathrm{~d}, 7.8)$ & $4.91 \mathrm{~d}(7.9)$ \\
\hline 11 & $1.99(\mathrm{~m}), 1.92(\mathrm{~m})$ & $2.22(\mathrm{~m}), 1.99(\mathrm{~m})$ & $2^{\prime \prime}$ & $3.92(\mathrm{~m})$ & $3.90(\mathrm{~m})$ \\
\hline 12 & 5.40 (br.s) & $5.39(\mathrm{t}, 3.4)$ & $3 "$ & $4.15(\mathrm{~m})$ & $4.11(\mathrm{~m})$ \\
\hline 15 & $2.27(\mathrm{~m}), 1.10(\mathrm{~m})$ & $2.23(\mathrm{~m})$ & $4 "$ & $4.45(\mathrm{~m})$ & $4.39(\mathrm{~m})$ \\
\hline 16 & $2.03(\mathrm{~m}), 1.87(\mathrm{~m})$ & $2.12(\mathrm{~m}), 1.92(\mathrm{~m})$ & $5^{\prime \prime}$ & $3.56(\mathrm{~m})$ & $3.54(\mathrm{~m})$ \\
\hline 18 & $3.17(\mathrm{dd}, 13.5,3.5)$ & $3.06(\mathrm{dd}, 13.3,4.8)$ & $6 "$ & $4.17(\mathrm{~m}), 4.05(\mathrm{~m})$ & $4.16(\mathrm{~m}), 4.03(\mathrm{~m})$ \\
\hline 19 & $1.71(\mathrm{~m}), 1.22(\mathrm{~m})$ & $2.54(\mathrm{~m}), 2.17(\mathrm{~m})$ & $1^{\prime \prime \prime}$ & 5.87 (br.s) & 5.82 (br.s) \\
\hline 21 & $1.32(\mathrm{~m}), 1.09(\mathrm{~m})$ & $2.16(\mathrm{~m}), 2.05(\mathrm{~m})$ & $2^{\prime \prime \prime}$ & 4.85 (br.s) & 4.83 (br.s) \\
\hline 22 & $1.83(\mathrm{~m}), 1.73(\mathrm{~m})$ & $1.98(\mathrm{~m}), 1.67(\mathrm{~m})$ & $3^{\prime \prime \prime}$ & $4.61(\mathrm{dd}, 9.4,2.9)$ & $4.59(\mathrm{~m})$ \\
\hline 23 & $9.61(\mathrm{~s})$ & $9.59(\mathrm{~s})$ & $4^{\prime \prime \prime}$ & $4.50(\mathrm{~m})$ & $4.47(\mathrm{~m})$ \\
\hline 24 & $1.42(\mathrm{~s})$ & $1.39(\mathrm{~s})$ & $5^{\prime \prime \prime}$ & $5.09(\mathrm{~m})$ & $5.05(\mathrm{~m})$ \\
\hline 25 & $1.04(\mathrm{~s})$ & $0.99(\mathrm{~s})$ & $6^{\prime \prime \prime}$ & $1.66(\mathrm{~d}, 6.1)$ & $1.63(\mathrm{~d}, 6.1)$ \\
\hline 26 & $1.07(\mathrm{~s})$ & $1.01(\mathrm{~s})$ & 1"'"' & $5.24(\mathrm{~d}, 7.5)$ & $5.22(\mathrm{~d}, 7.5)$ \\
\hline 27 & $1.20(\mathrm{~s})$ & $1.15(\mathrm{~s})$ & $2^{\prime \prime \prime \prime}$ & $4.06(\mathrm{~m})$ & $4.03(\mathrm{~m})$ \\
\hline 29 & $0.90(\mathrm{~s})$ & $4.73(\mathrm{~s}), 4.66(\mathrm{~s})$ & 3"'" & $4.12(\mathrm{~m})$ & $4.12(\mathrm{~m})$ \\
\hline \multirow[t]{2}{*}{30} & $0.88(\mathrm{~s})$ & & $4^{\prime \prime \prime \prime}$ & $4.17(\mathrm{~m})$ & $4.14(\mathrm{~m})$ \\
\hline & & & $5^{\prime \prime \prime \prime}$ & $4.24(\mathrm{~m}), 3.58(\mathrm{~m})$ & $4.20(\mathrm{~m}), 3.55(\mathrm{~m})$ \\
\hline
\end{tabular}

${ }^{a}$ Recorded in $\mathrm{C}_{5} \mathrm{D}_{5} \mathrm{~N}$ at $500 \mathrm{MHz} ;{ }^{\mathrm{b}}$ Recorded in $\mathrm{C}_{5} \mathrm{D}_{5} \mathrm{~N}$ at $600 \mathrm{MHz}$.

Table 2. The ${ }^{13} \mathrm{C}-\mathrm{NMR}(150 \mathrm{MHz})$ spectral data $(\delta(\mathrm{ppm}))$ of compounds 1 and 2.

\begin{tabular}{|c|c|c|c|c|c|c|c|c|}
\hline No. & $\delta_{H}(1)^{a}$ & $\delta_{H}(2)^{b}$ & No. & $\delta_{H}(1)^{a}$ & $\delta_{H}(2) b$ & No. & $\delta_{H}(1)^{a}$ & $\delta_{H}(2)^{b}$ \\
\hline 1 & $47.4 \mathrm{CH}_{2}$ & $47.4 \mathrm{CH}_{2}$ & 22 & $32.2 \mathrm{CH}_{2}$ & $37.4 \mathrm{CH}_{2}$ & $5^{\prime \prime}$ & $77.0 \mathrm{CH}$ & $76.9 \mathrm{CH}$ \\
\hline 2 & $67.9 \mathrm{CH}$ & $67.9 \mathrm{CH}$ & 23 & $206.3 \mathrm{CH}$ & $206.3 \mathrm{CH}$ & $6^{\prime \prime}$ & $60.9 \mathrm{CH}_{2}$ & $61.0 \mathrm{CH}_{2}$ \\
\hline 3 & $76.9 \mathrm{CH}$ & $76.9 \mathrm{CH}$ & 24 & $10.5 \mathrm{CH}_{3}$ & $10.5 \mathrm{CH}_{3}$ & Rha & & \\
\hline 4 & $56.4 \mathrm{C}$ & $56.4 \mathrm{C}$ & 25 & $17.0 \mathrm{CH}_{3}$ & $17.0 \mathrm{CH}_{3}$ & $1^{\prime \prime \prime}$ & $102.2 \mathrm{CH}$ & $102.1 \mathrm{CH}$ \\
\hline 5 & $47.9 \mathrm{CH}$ & $47.9 \mathrm{CH}$ & 26 & $17.3 \mathrm{CH}_{3}$ & $17.3 \mathrm{CH}_{3}$ & $2^{\prime \prime \prime}$ & $71.9 \mathrm{CH}$ & $71.9 \mathrm{CH}$ \\
\hline 6 & $20.5 \mathrm{CH}_{2}$ & $20.5 \mathrm{CH}_{2}$ & 27 & $25.9 \mathrm{CH}_{3}$ & $25.8 \mathrm{CH}_{3}$ & $3^{\prime \prime \prime}$ & $83.0 \mathrm{CH}$ & $83.0 \mathrm{CH}$ \\
\hline 7 & $32.2 \mathrm{CH}_{2}$ & $32.2 \mathrm{CH}_{2}$ & 28 & $176.3 \mathrm{C}$ & $175.6 \mathrm{C}$ & $4^{\prime \prime \prime}$ & $72.7 \mathrm{CH}$ & $72.7 \mathrm{CH}$ \\
\hline 8 & $39.8 \mathrm{C}$ & $39.8 \mathrm{C}$ & 29 & $33.0 \mathrm{CH}_{3}$ & $107.3 \mathrm{CH}_{2}$ & $5^{\prime \prime \prime}$ & $69.8 \mathrm{CH}$ & $69.8 \mathrm{CH}$ \\
\hline 9 & $47.8 \mathrm{CH}$ & $47.8 \mathrm{CH}$ & 30 & $23.5 \mathrm{CH}_{3}$ & & $6^{\prime \prime \prime}$ & $18.2 \mathrm{CH}_{3}$ & $18.2 \mathrm{CH}_{3}$ \\
\hline 10 & $38.2 \mathrm{C}$ & $38.1 \mathrm{C}$ & Glc-I & & & Xyl & & \\
\hline 11 & $23.1 \mathrm{CH}_{2}$ & $23.6 \mathrm{CH}_{2}$ & $1^{\prime}$ & $95.5 \mathrm{CH}$ & $95.5 \mathrm{CH}$ & $1^{\prime \prime \prime \prime}$ & $107.1 \mathrm{CH}$ & $107.1 \mathrm{CH}$ \\
\hline 12 & $122.4 \mathrm{CH}$ & $122.8 \mathrm{CH}$ & $2^{\prime}$ & $73.6 \mathrm{CH}$ & $73.6 \mathrm{CH}$ & $2^{\prime \prime \prime \prime}$ & $75.5 \mathrm{CH}$ & $75.5 \mathrm{CH}$ \\
\hline 13 & $144.0 \mathrm{C}$ & $143.3 \mathrm{C}$ & $3^{\prime}$ & $78.5 \mathrm{CH}$ & $78.4 \mathrm{CH}$ & $3^{\prime \prime \prime \prime}$ & $78.2 \mathrm{CH}$ & $78.1 \mathrm{CH}$ \\
\hline 14 & $42.0 \mathrm{C}$ & $42.0 \mathrm{C}$ & $4^{\prime}$ & $70.8 \mathrm{CH}$ & $70.6 \mathrm{CH}$ & $4^{\prime \prime \prime \prime}$ & $70.8 \mathrm{CH}$ & $70.8 \mathrm{CH}$ \\
\hline 15 & $28.0 \mathrm{CH}_{2}$ & $28.0 \mathrm{CH}_{2}$ & $5^{\prime}$ & $77.8 \mathrm{CH}$ & $77.7 \mathrm{CH}$ & $5^{\prime \prime \prime \prime}$ & $67.1 \mathrm{CH}_{2}$ & $67.1 \mathrm{CH}_{2}$ \\
\hline 16 & $23.7 \mathrm{CH}_{2}$ & $23.3 \mathrm{CH}_{2}$ & $6^{\prime}$ & $69.0 \mathrm{CH}_{2}$ & $69.1 \mathrm{CH} 2$ & & & \\
\hline 17 & $46.8 \mathrm{C}$ & $47.1 \mathrm{C}$ & Gls-II & & & & & \\
\hline 18 & $41.5 \mathrm{CH}$ & $47.3 \mathrm{CH}$ & $1^{\prime \prime}$ & $104.7 \mathrm{CH}$ & $104.7 \mathrm{CH}$ & & & \\
\hline 19 & $46.0 \mathrm{CH}_{2}$ & $41.4 \mathrm{CH}_{2}$ & $2^{\prime \prime}$ & $75.2 \mathrm{CH}$ & $75.2 \mathrm{CH}$ & & & \\
\hline 20 & $30.6 \mathrm{C}$ & $148.1 \mathrm{C}$ & $3^{\prime \prime}$ & $76.2 \mathrm{CH}$ & $76.2 \mathrm{CH}$ & & & \\
\hline 21 & $33.8 \mathrm{CH}_{2}$ & $29.9 \mathrm{CH}_{2}$ & $4^{\prime \prime}$ & $77.1 \mathrm{CH}$ & $77.1 \mathrm{CH}$ & & & \\
\hline
\end{tabular}

The $\alpha$-configuration of the L-rhamnose (Rha) unit was evidenced by the singlet signal $\delta_{\mathrm{H}} 5.87$ (br.s) observed for the anomeric proton H-1"' [12]. Therefore, 1 was identified as $2 \alpha, 3 \beta, 23,29$ tetrahydroxyolean-12-en-28-oic acid-O- $\beta$-D-xylpyranosyl- $(1 \rightarrow 3)-O$ - $\alpha$-L-rhamnopyranosyl-(14)-O- $\beta$-Dglucopyranosyl-(1 $\rightarrow$ 6)- $\beta$-D-glucopyranosyl ester $(\mathbf{1})$, trivially named akebiaoside $\mathrm{K}$. 

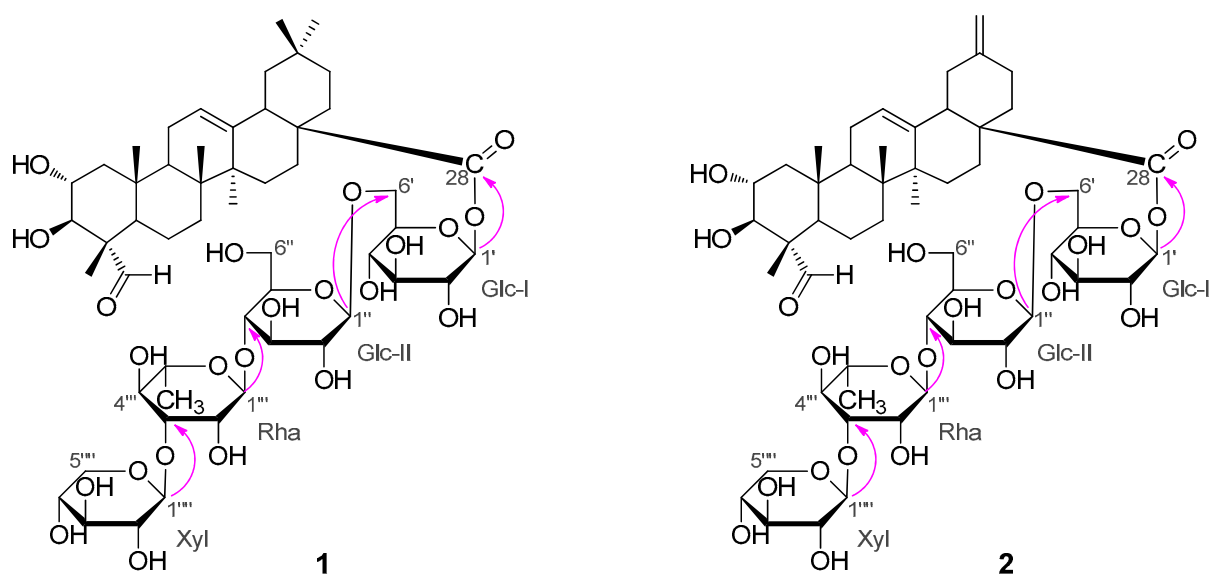

Figure 2. Selected HMBC correlations of compounds 1 and 2.

Compound 2 was obtained as a white amorphous powder with molecular formula $\mathrm{C}_{52} \mathrm{H}_{80} \mathrm{O}_{23}$ as determined by HR-ESI-MS analysis $\left([\mathrm{M}+\mathrm{Na}]^{+} m / z\right.$ 1095.4965, calcd. 1095.4983). Its spectral features and physicochemical properties suggested 2 was also a triterpenoid saponin. Careful comparison revealed that the ${ }^{1} \mathrm{H}$ - and ${ }^{13} \mathrm{C}-\mathrm{NMR}$ spectral data of the aglycone part of 2 were quite close to those of 2 $\alpha, 3 \beta$-dihydroxy-23-oxo-30-norolean-12,20(29)-dien-28-oic acid [14], a known noroleanane triterpene which was also obtained in this study as compound 6, suggesting that the aglycone unit of $\mathbf{2}$ was the same as $\mathbf{6}$. This assignment was supported by the acid hydrolysis of $\mathbf{2}$ which furnished the free aglycone identified as $\mathbf{6}$, and the monosaccharide compounents concomitantly obtained from the acid hydrolysis of 2 were identified as D-glucose, L-rhamnose and D-xylose in the ratio of 2:1:1 based on GC-MS analysis of their chiral derivatives (see experimental section), supporting the presence of the same four sugar moieties as those in $\mathbf{1}$. On the basis of combined analysis of ${ }^{1} \mathrm{H}-{ }^{1} \mathrm{H}$ COSY, HMQC and HMBC spectra, all proton and carbon signals were assigned (Tables 1 and 2). The $\beta$-anomeric configuration of the D-glucose units (Glc-I and Glc-II) and the xylose (Xyl) moiety were determined from their coupling constants of ${ }^{3} J_{\mathrm{H}^{\prime}, \mathrm{H} 2^{\prime}}(8.2 \mathrm{~Hz}),{ }^{3} J_{\mathrm{H} 1^{\prime \prime}, \mathrm{H} 2^{\prime \prime}}(7.9 \mathrm{~Hz})$

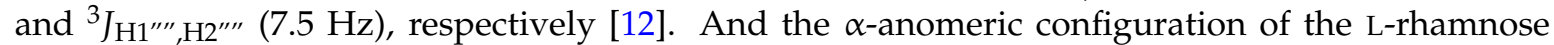
unit was judged by the singlet signal at $\delta_{\mathrm{H}} 5.82$ (br.s) for the anomeric proton H-1"' [12]. In the HMBC spectrum, ${ }^{1} \mathrm{H}_{-}{ }^{13} \mathrm{C}$ long-range correlation of $\mathrm{H}-1^{\prime}\left(\delta_{\mathrm{H}} 6.14\right)$ with $\mathrm{C}-28\left(\delta_{\mathrm{C}} 175.6\right)$ was displayed, which evidenced the glycoside linkage of Glc-I at C-1' with the aglycone at C-28. The exhibition of obvious HMBC correlations of $\mathrm{H}-1^{\prime \prime}\left(\delta_{\mathrm{H}} 4.91\right)$ with C-6 ${ }^{\prime}\left(\delta_{\mathrm{C}} 69.1\right)$, of $\mathrm{H}-1^{\prime \prime \prime}\left(\delta_{\mathrm{H}} 5.82\right)$ with C-5" $\left(\delta_{C} 76.9\right)$, and of H-1"'” $\left(\delta_{\mathrm{H}} 5.22\right)$ with $\mathrm{C}-3^{\prime \prime \prime}\left(\delta_{\mathrm{C}}\right.$ 83.0) confirmed the oligosaccharide sequence in 2 as shown in Figure 2. Based upon the above information, the strcuture of compound 2 was elucidated as $2 \alpha, 3 \beta$-dihydroxy-23-oxo-29-norolean-12,20(30)-dien-28-oic acid O- $\beta$-D-xylpyranosyl$(1 \rightarrow 3)-O-\alpha$-L-rhamnopy-ranosyl-( $\rightarrow 4$ )-O- $\beta$-D-glucopyranosyl-( $1 \rightarrow 6)-\beta$-D-glucopyranosyl ester $(2)$, trivially named akebiaoside $\mathrm{N}$.

The five known compounds were identified as akemisaponin I (3) [7], mutongsaponin B (4) [6], $2 \alpha, 3 \beta$-dihydroxy-23-oxo-olean-12-en-28-oic acid (5) [11], 2 $\alpha, 3 \beta$-dihydroxy-23-oxo-30-norolean-12,20 (29)-dien-28-oic acid (6) [14] and arjunolic acid (7) [15], by comparison of their spectral data $\left({ }^{1} \mathrm{H}\right.$ - and ${ }^{13} \mathrm{C}-\mathrm{NMR}$ and $\left.\mathrm{MS}\right)$ to those reported in the literature. They were all isolated from the leaves of $A$. trifoliata for the first time.

Compounds 1-7 were evaluated for their in vitro cytotoxicity against human cancer cell lines A549, HeLa and HepG2, using a MTT method as described. The resulting IC $_{50}$ values are displayed in Table 3, compared to adriamycin as positive control. Compounds 5 and 7 showed moderate cytotoxicity against all the three cancer cell lines, with $\mathrm{IC}_{50}$ values ranging from 22.7 to $38.1 \mu \mathrm{M}$. Meanwhile, no obvious activity was detected for the four saponins 1-4. This result reveals an obvious negative effect on the cytotoxicity when the triterpenes were linked with the linear tetrasaccharide 
chain at C-28. Comparison of the chemical structures and their cytotoxicity of $\mathbf{5}$ versus $\mathbf{6}$ indicated that the replacement of the structure fragment C-20(Me $)_{2}$ by the exocyclic double bond of C-20(29) also had a negative effect on the cytotoxicity.

Table 3. Cytotoxicity of compounds $1-7\left(\mathrm{IC}_{50}, \mu \mathrm{M}\right)$.

\begin{tabular}{cccc}
\hline Compounds & A549 & HeLa & HepG2 \\
\hline $\mathbf{1}-\mathbf{4}$ & $>100$ & $>100$ & $>100$ \\
$\mathbf{5}$ & $30.19 \pm 4.55$ & $22.74 \pm 1.96$ & $37.97 \pm 7.57$ \\
$\mathbf{6}$ & $>100$ & $>100$ & $>100$ \\
$\mathbf{7}$ & $33.58 \pm 3.13$ & $24.35 \pm 1.49$ & $38.14 \pm 1.63$ \\
Adriamycin & $0.69 \pm 0.07$ & $0.47 \pm 0.06$ & $1.22 \pm 0.02$ \\
\hline Values represent mean $+\mathrm{SD}(n=3)$ based on three individual experiments.
\end{tabular}

These compounds were further tested for their $\alpha$-glucosidase inhibitory activity with acarbose used as a reference compound. Compounds 5-7 were revealed to show strong $\alpha$-glucosidase inhibitory activity, with $\mathrm{IC}_{50}$ values of $0.047,0.220$ and $0.040 \mathrm{mM}$, respectively, which were about two to ten-fold stronger than acarbose $\left(\mathrm{IC}_{50} 0.409 \mathrm{mM}\right)$. These results suggested that triterpenes $5-7$ from the leaves of $A$. trifoliata are effective $\alpha$-glucosidase inhibitors with potential value for development as effective hypoglycemic agents for diabetes chemotherapy [16]. Like in the cytotoxicity bioassay, no obvious $\alpha$-glucosidase inhibitory activity was detected for the four triterpenoid saponins 1-4, indicating that a negative effect of the tetrasaccharide chain linked at C-28 on the $\alpha$-glucosidase inhibitory activity was also evident.

A. trifoliata is a medicinal plant naturally widely distributed in the eastern part of Asia. Its air-dried stems and fruits have long been used in China as an antiphlogistic, antineoplastic and diuretic agent. To date phytochemical investigations have revealed a series of triterpenes and triterpene saponins from this plant species. However, those studies were mainly focused on the stems and fruits, and seldom concentrated on the leaves. Our present study revealed that the leaves of $A$. trifoliata is also rich in triterpenes and triterpene saponins. At the same time, however, it is also demonstrated that much future work is needed to unravel the complexity of the chemical constituents in the leaves of A. trifoliata.

\section{Materials and Methods}

\subsection{General Information}

Optical rotation were measured on a Perkin-Elmer 341 polarimeter (Perkin-Elmer, Waltham, MA, USA) with $\mathrm{MeOH}$ as solvent at the wavelength of $589 \mathrm{~nm}$ and $20{ }^{\circ} \mathrm{C}$ to obtain their specific optical rotation $[\alpha]$ values after calculation. ESI-MS data were obtained using a MDS SCIEX API 2000 LC/MS/MS system (Applied Biosystems, Foster City, CA, USA) in both positive and negative ion modes in the range of $m / z 50-1000$ after the test solutions were directly injected into the ESI source by a syringe pump. HR-ESI-MS mass spectra were obtained on a Bruker maXis instrument (Bruker Daltonik $\mathrm{GmbH}$, Bremen, Germany) in a positive ion mode after direct injection of the test solutions. Nuclear magnetic resonance (NMR) spectra were recorded on a Bruker Advance 600 instrument (Bruker, Fällanden, Switzerland) or Bruker Ascend-500 spectrometer (Bruker BioSpin GmbH, Rheistetten, Germany). Preparative HPLC was carried out on a CXTH P3000 HPLC pump and a UV 3000 UV-Vis Detector with a Fuji-C18 column (10 $\mu \mathrm{m}-100$ A, ChuangXinTongHeng Science and Technology Co., Ltd., Beijing, China); medium pressure liquid chromatography (MPLC) was performed using a CXTH P3000 HPLC pump, a UV 3000 UV-Vis Detector and a C18 column $(400 \times 25$ mM i.d., $50 \mu \mathrm{M}$, YMC Co. Ltd., Kyoto, Japan).

Column chromatography (CC) was performed with silica gel (200-300 mesh, Qingdao Haiyang Chemical Co., Qingdao, China), YMC ODS-A (50 m, YMC Co. Ltd.), and Sephadex LH-20 (Pharmacia 
Fine Chemical Co., Ltd., Uppsala, Sweden). Analytical grade petroleum ether (b.p. $60-90{ }^{\circ} \mathrm{C}$ ), methanol, ethyl acetate, chloroform, $n$-butanol, acetone were purchased from Tianjin Fuyu Fine Chemical Industry Co. (Tianjin, China); HPLC grade methanol was purchased from J \& K Chemical Ltd. (Beijing, China); Fractions were monitored by pre-coated $\mathrm{HSGF}_{254}$ TLC (Yantai Jiangyou Silica Gel Co., Ltd., Yantai, China), and spot detection was performed under fluorescent light $(\lambda=254 \mathrm{~nm})$, and then spraying $10 \% \mathrm{H}_{2} \mathrm{SO}_{4}$ in ethanol, followed by heating. Pyridine- $d_{5}$, DMSO- $d_{6}$, 3-(4,5-dimethylthiazol-2-yl)-2,5-diphenyltetrazolium bromide (MTT) and $\alpha$-glucosidase were purchased from Sigma Chemical Co. (Sigma-Aldrich, St. Louis, MO, USA). RPMI-1640 medium and fetal calf serum were purchased from Gibco BRL (Gaithersburg, MD, USA). Adriamycin was obtained from Pfizer Italia SRL (Roma, Italy). $p$-Nitrophenyl- $\alpha$-D-glucopyranoside (PNPG) and acarbose were obtained from Tokyo Chemical Industry Co., Ltd. (Tokyo, Japan).

\subsection{Plant Materials}

The leaves of Akebia trifoliata were collected in August 2014, at Sangzhi, Hunan Province, China, were identified by Prof. Fu-Wu Xing at the South China Botanical Garden, the Chinese Academy of Sciences (CAS). A voucher specimen (No. 20140815) was deposited at the Laboratory of Bioorganic Chemistry of the South China Botanical Garden, Chinese Academy of Sciences.

\subsection{Extraction and Isolation}

Powdered air-dried leaves of $A$. trifoliate (dried weight $3.5 \mathrm{~kg}$ ) were extracted three times with $95 \%$ $\mathrm{EtOH}(10 \mathrm{~L} \times 3)$ at room temperature for 2 days each time. The extract was concentrated in vacuo to give a dark brown residue, which was suspended in $3 \mathrm{~L}$ of water and then sequentially extracted with petroleum ether $(3 \mathrm{~L} \times 3)$, ethyl acetate $($ EtOAc, $3 \mathrm{~L} \times 3)$ and $n$-butanol $(n-\mathrm{BuOH}, 3 \mathrm{~L} \times 3)$ to yield a petroleum ether-soluble fraction $(31 \mathrm{~g})$, an EtOAc-soluble fraction $(168 \mathrm{~g})$, and a $n$-BuOH-soluble fraction $(245 \mathrm{~g})$ after condensation to dryness in vacuo. The EtOAc-soluble fraction was subjected to silica gel CC $\left(1000 \mathrm{~mm} \times 105 \mathrm{~mm}\right.$ i.d.) eluted with a gradient of $\mathrm{CHCl}_{3}-\mathrm{MeOH}(97: 3-0: 100, v / v)$ to give fractions $\mathrm{F}_{1}-\mathrm{F}_{10}$ after pooled according to their TLC profiles. Fraction $\mathrm{F}_{5}(7.1 \mathrm{~g})$, obtained from the elution of $\mathrm{CHCl}_{3} / \mathrm{MeOH}$ of 85:15 $(v / v)$, was subjected to a silica gel $\mathrm{CC}(800 \times 50 \mathrm{~mm}$ i.d. $)$ and successively eluted with $\mathrm{CHCl}_{3} / \mathrm{MeOH}(98: 2-90: 10, v / v)$ to yield sub-fractions $\mathrm{F}_{5-1}-\mathrm{F}_{5-6}$. Sub-fraction $\mathrm{F}_{5-3}(1.57 \mathrm{~g})$ was separated by MPLC using $\mathrm{MeOH} / \mathrm{H}_{2} \mathrm{O}(60: 40-100: 0, v / v)$ system at a flow rate of $10 \mathrm{~mL} / \mathrm{min}$, and further purified by passing through a Sephadex LH-20 column $(1500 \mathrm{~mm} \times 25 \mathrm{~mm}$ i.d.) eluted with $\mathrm{MeOH}$ to obtain compounds $5(5.2 \mathrm{mg})$ and $6(3.8 \mathrm{mg})$. Sub-fraction $\mathrm{F}_{5-5}(2.3 \mathrm{~g})$ was separated by MPLC using a gradient of $\mathrm{MeOH} / \mathrm{H}_{2} \mathrm{O}(30: 70-80: 20, v / v)$ at a flow rate of $10 \mathrm{~mL} / \mathrm{min}$ to obtain six sub fractions $\left(\mathrm{F}_{5-5-1}-\mathrm{F}_{5-5-6}\right)$, and sub fraction $\mathrm{F}_{5-5-5}$ was purified by preparative HPLC with a Fuji-C18 column $(10 \mu \mathrm{m}-100 \mathrm{~A})$ using $73 \%$ methanol in water $(v / v)$ as a mobile phase at flow rate of $8 \mathrm{~mL} / \mathrm{min}$ to give compound 7 (15.6 mg).

The $n$ - $\mathrm{BuOH}$-soluble fraction $(245 \mathrm{~g})$ was dissolved in water and passed through a HP-20 column eluted with distilled water and $90 \% \mathrm{EtOH}$. Column chromatography of the $90 \% \mathrm{EtOH}$ eluate portion (128 g) on silica gel (200-300 mesh) and elution with a gradient system of $\mathrm{CHCl}_{3} / \mathrm{MeOH}$ $(85: 15-0: 100, v / v)$ to give six fractions (G1-G6) after pooled according to their TLC profiles. Fraction G3 $(18 \mathrm{~g})$, obtained from the elution of $\mathrm{CHCl}_{3} / \mathrm{MeOH}$ of 85:15 $(v / v)$, was subjected to a silica gel $\mathrm{CC}(600 \times 50 \mathrm{~mm}$ i.d. $)$ and successively eluted with $\mathrm{CHCl}_{3} / \mathrm{MeOH}(85: 15-40: 60, v / v)$ to yield five sub-fractions $\left(\mathrm{G}_{3-1}-\mathrm{F}_{3-4}\right)$. Sub-fraction $\mathrm{G}_{3-2}(2.7 \mathrm{~g})$ was separated by MPLC using a gradient of $\mathrm{MeOH} / \mathrm{H}_{2} \mathrm{O}(20: 80-100: 0, v / v)$ at a flow rate of $10 \mathrm{~mL} / \mathrm{min}$ to obtain nine sub fractions $\left(\mathrm{G}_{3-2-1}-\mathrm{G}_{3-2-9}\right)$, and $\mathrm{G}_{3-2-2}$ was purified by preparative HPLC with a Fuji-C18 column $(10 \mu \mathrm{m}-100 \mathrm{~A})$ using a gradient of $\mathrm{MeOH} / \mathrm{H}_{2} \mathrm{O}(50: 50-70: 30, v / v)$ as a mobile phase at flow rate of $10 \mathrm{~mL} / \mathrm{min}$ to give compound 2 (6.4 mg). $\mathrm{G}_{3-2-6}$ was purified by preparative HPLC with a Fuji-C18 column $(10 \mu \mathrm{m}-100 \mathrm{~A})$ using a gradient of methanol in water $(45: 55-63: 37, v / v)$ as a mobile phase at flow rate of $10 \mathrm{~mL} / \mathrm{min}$ to give compound $3(10 \mathrm{mg})$. G $\mathrm{G}_{3-2-7}$ was purified by a Sephadex LH-20 column (1500 $\mathrm{mm} \times 25 \mathrm{~mm}$ i.d.) eluted with $\mathrm{MeOH}$ to afford compound $\mathbf{1}(12 \mathrm{mg})$. Fraction $\mathrm{G} 5$ was subjected to $\mathrm{CC}$ on silica 
gel (200-300 mesh) eluted with a gradient of $\mathrm{CHCl}_{3} / \mathrm{MeOH}$ (80:20-40:60) and Sephadex LH-20 with $\mathrm{MeOH}$ to furnish 4 (4.1 mg).

Compound 1. White amorphous powder. $[\alpha]_{D}^{20}:-7.3(c 0.33, \mathrm{MeOH})$. ESI-MS $(+) m / z: 1111[\mathrm{M}+\mathrm{Na}]^{+}$; ESI-MS (-) $m / z: 1087[\mathrm{M}-\mathrm{H}]^{-}$. HR-ESI-MS (pos.) $m / z: 1111.5297$ (calcd for $\mathrm{C}_{53} \mathrm{H}_{84} \mathrm{NaO}_{23}, 1111.5296$ ). For ${ }^{1} \mathrm{H}-\mathrm{NMR}\left(600 \mathrm{MHz}, \mathrm{C}_{5} \mathrm{D}_{5} \mathrm{~N}\right)$ and ${ }^{13} \mathrm{C}-\mathrm{NMR}\left(150 \mathrm{MHz}, \mathrm{C}_{5} \mathrm{D}_{5} \mathrm{~N}\right)$ data, see Tables 1 and 2.

Compound 2. White amorphous powder. $[\alpha]_{D}^{20}:+5.03$ (c 0.34, MeOH). HR-ESI-MS (pos.) $m / z: 1095.4965$ (calcd for $\left.\mathrm{C}_{52} \mathrm{H}_{80} \mathrm{NaO}_{23}, 1095.4983\right)$. For ${ }^{1} \mathrm{H}-\mathrm{NMR}\left(600 \mathrm{MHz}, \mathrm{C}_{5} \mathrm{D}_{5} \mathrm{~N}\right)$ and ${ }^{13} \mathrm{C}-\mathrm{NMR}$ $\left(150 \mathrm{MHz}, \mathrm{C}_{5} \mathrm{D}_{5} \mathrm{~N}\right)$ data, see Tables 1 and 2.

\subsection{Acid Hydrolysis of $\mathbf{1}$ and $\mathbf{2}$}

Each of compounds of $\mathbf{1}$ and $\mathbf{2}(3 \mathrm{mg})$ was heated in $2 \mathrm{M} \mathrm{HCl}(4 \mathrm{~mL})$ at $90^{\circ} \mathrm{C}$ for $2 \mathrm{~h}$. The reaction mixture was extracted with EtOAc $(3 \times 4 \mathrm{~mL})$. The EtOAc extract was purified by passing through a Sephadex LH-20 column (1500 mm $\times 25 \mathrm{~mm}$ i.d.) eluted with $\mathrm{MeOH}$. By TLC comparison, the free aglycone of $\mathbf{1}$ was determined to be identical as $\mathbf{5}$, while that of $\mathbf{2}$ was identified as the same as 6, respectively. The aqueous layer was concentrated under reduced pressure to dryness to give a sugar-containing residue, which was reacted with L-cysteine methyl ester hydrochloride in pyridine at $60^{\circ} \mathrm{C}$ for $2 \mathrm{~h}$, then added with $\mathrm{N}, \mathrm{O}$-bis(trimethylsilyl)trifluoroacetamide (BSTFA) and stirred under reflux at $60^{\circ} \mathrm{C}$ for $10 \mathrm{~h}$. The supernatant was then analyzed by GC-MS using a GCMS-QP2010 PLUS instrument, HP-5ms capillary column (30 m, $0.25 \mathrm{~mm}$ ID), Helium at constant rate of $46.5 \mathrm{~cm} / \mathrm{s}$, $1 \mu \mathrm{L}$ injection volume, injector temperature at $230^{\circ} \mathrm{C}$, temperature program as $2{ }^{\circ} \mathrm{C} / \mathrm{min}$ to $180{ }^{\circ} \mathrm{C}$, then $20^{\circ} \mathrm{C} / \mathrm{min}$ to $280^{\circ} \mathrm{C}$. Electron ionization mode was used at $70 \mathrm{eV}$. In the acid hydrolysate of 1 and 2, D-glucose, L-rhamnose and D-xylose were confirmed by comparison of their retention times of their derivatives with those of authentic D-glucose ( $\left.t_{R} 11.852 \mathrm{~min}\right)$, L-rhamnose ( $t_{R} 5.292 \mathrm{~min}$ ) and D-xylose ( $\left.t_{R} 6.842 \mathrm{~min}\right)$ derivatives prepared in the same way, respectively.

\subsection{Cytotoxic Assay}

Compounds 1-7 were testeded for their cytotoxity against A549 (human lung adenocarcinoma), HeLa (human cervical carcinoma) and HepG2 (human liver hepatocellular carcinoma) cell lines. The three tumor cell lines were obtained from Kunming Institute of Zoology, Chinese Academy of Sciences. The cytotoxic activity of tested chemicals were assayed according to the MTT method using 96 well plates [17]. Briefly, the cells were cultured in RPMI-1640 medium, supplemented with $10 \%$ fetal bovine serum in a humidified atmosphere with $5 \% \mathrm{CO}_{2}$ at $37^{\circ} \mathrm{C} .100 \mu \mathrm{L}$ adherent cells at the density of $5 \times 10^{4}$ cell $/ \mathrm{mL}$ was seeded into each well of 96 -well cell culture plates and incubated in $5 \% \mathrm{CO}_{2}$ at $37^{\circ} \mathrm{C}$ for $24 \mathrm{~h}$ to form a monolayer on the flat bottoms. Then, the supernatant per well was removed and subsequently added with $100 \mu \mathrm{L}$ fresh medium and $100 \mu \mathrm{L}$ medium containing a test compound. The plate was then incubated in $5 \% \mathrm{CO}_{2}$ at $37^{\circ} \mathrm{C}$. After $72 \mathrm{~h}, 20 \mu \mathrm{L}$ of $5 \mathrm{mg} / \mathrm{mL}$ MTT in DMSO was added into each well and incubated for $4 \mathrm{~h}$. The supernatant per well was carefully removed and $150 \mu \mathrm{L}$ DMSO was added. The plate was then vortex shaken for $15 \mathrm{~min}$ to dissolve blue formazan crystals. The optical density (OD) of each well was measured on a Genois microplate reader (Tecan GENios, Männedorf, Switzerland) at the wavelength of $570 \mathrm{~nm}$. All experiments were performed in triplicate and adriamycin was used as a positive control. In each experiment, each of the tumor cell lines was exposed to the test compound at concentrations 50, 25, 12.5, 6.25, $3.125,1.5625 \mu \mathrm{g} / \mathrm{mL}$. The inhibitory rate of cell growth was calculated according to the following formula: Inhibition rate $(\%)=\left(\mathrm{OD}_{\text {control }}-\mathrm{OD}_{\text {treated }}\right) / \mathrm{OD}_{\text {control }} \times 100 \% . \mathrm{IC}_{50}$ values were calculated by SPSS 16.0 statistic software. The values were based on three individual experiments and expressed as means \pm standard deviation (SD). 


\section{6. $\alpha$-Glucosidase Inhibition Assay}

The $a$-glucosidase inhibitory activity of 1-7 were determined spectrophotometrically in a 96-well microtiter plate based on $p$-nitrophenyl- $\alpha$-D-glucopyranoside (PNPG) as a substrate following the method described in literature with slight modifications [18,19]. In brief, $\alpha$-glucosidase $(20 \mu \mathrm{L}$, $0.8 \mathrm{U} / \mathrm{mL})$ and various concentrations $(500,250,125,62.5,31.25,15.625 \mu \mathrm{g} / \mathrm{mL})$ of tested compounds $(120 \mu \mathrm{L})$ in $67 \mathrm{mM}$ phosphate buffer ( $\mathrm{pH}$ 6.8) were mixed at room temperature for $10 \mathrm{~min}$. Reactions were initiated by addition of $5.0 \mathrm{mM}$ PNPG $(20 \mu \mathrm{L})$. The reaction mixture was incubated for $15 \mathrm{~min}$ at $37^{\circ} \mathrm{C}$ in a final volume of $160 \mu \mathrm{L}$. Then, $0.2 \mathrm{M} \mathrm{Na}_{2} \mathrm{CO}_{3}(80 \mu \mathrm{L})$ was added to the incubation solution to stop the reaction. The activities were detected in a 96-well plate, and the absorbance was determined at $405 \mathrm{~nm}$ (for $p$-nitrophenol). The negative blank was set by adding phosphate buffer instead of the sample via the same way as the test. Acarbose was utilized as positive control. The blank was set by adding phosphate buffer instead of the $\alpha$-glucosidase using the same method. Inhibition rate $(\%)=\left[\left(\mathrm{OD}_{\text {negative control }}-\mathrm{OD}_{\text {blank }}\right)-\left(\mathrm{OD}_{\text {test }}-\mathrm{OD}_{\text {test blank }}\right)\right] /\left(\mathrm{OD}_{\text {negative blank }}-\mathrm{OD}_{\text {blank }}\right) \times 100 \%$. $\mathrm{IC}_{50}$ values of the samples were calculated using the Microsoft Office Excel soft.

\section{Conclusions}

Seven pentacyclic triterpenoids, including two new triterpene saponins $\mathbf{1}$ and 2, were isolated from the leaves of $A$. trifoliata. Their structures were identified by spectroscopic and chemical means, including NMR and HRESIMS. All the compounds were isolated from the leaves of A. trifoliata for the first time. Triterpenes 5 and $\mathbf{7}$ were found to show moderate in vitro cytotoxicity against human tumor A549, HeLa and HepG2 cell lines. Triterpenes 5-7 were further revealed to show significant in vitro $\alpha$-glucosidase inhibitory activity, much more potent than the reference compound acarbose. No obvious inhibitory effects were displayed by the triterpene saponins 1-4 in either bioactivity assay. The present study indicate that the leaves of $A$. trifoliata are rich in triterpenoids which are potential functional chemicals worthy of further investigation.

Supplementary Materials: The following are available online as supporting information at: http://www.mdpi. com/1420-3049/21/7/962/s1, HR-ESI-MS and NMR spectra data of compounds 1 and 2.

Acknowledgments: This research was supported by the National Natural Science Foundation of China (31470422, 31270406 and 31500291), the Natural Science Foundation of Guangdong Province (2014A030313742), and the Science and Technology Project of Guangdong Province (2014B020206003).

Author Contributions: Q.-L.X. and J.W. performed the isolation and structure elucidation of the chemicals and participated in the bioassay experiments. Q.-L.X. also contributed the preparation of the manuscript. L.-M.D. carried out the ethanol extraction and contribute part of the structural identification. Q.Z. and B.L. partially contribute the bioassays. Y.-X.J. carried out the GC-MS analysis. H.-F.W. contribute the collection of the plant material. J.-W.T. planned, designed and organized the whole research of this study. All authors approved the final version manuscript.

Conflicts of Interest: The authors declare no conflict of interest.

\section{References}

1. Li, L.; Yao, X.; Zhong, C.; Chen, X.; Huang, H. Akebia: A potential new fruit crop in China. HortScience 2010, 45, 4-10.

2. Wang, Z.; Zhong, C.; Bu, F.; Peng, D.; Peng, J.; Yuan, F. Akebia-A valuable wild fruit under domestication. Agric. Sci. Technol. 2005, 6, 12-18.

3. Li, L.; Chen, X.Z.; Yao, X.H.; Tian, H.; Huang, H.W. Geographic distribution and resources status of three important Akebia species. J. Wuhan Bot. Res. 2010, 28, 497-506.

4. Jiangsu New Medical College. Dictionary of Chinese Herbal Medicines; Shanghai Science and Technology Press: Shanghai, China, 1995; p. 169.

5. Mimaki, Y.; Kuroda, M.; Yokosuka, A.; Harada, H.; Fukushima, M.; Sashida, Y. Triterpenes and triterpene saponins from the stems of Akebia trifoliata. Chem. Pharm. Bull. 2003, 51,960-965. [CrossRef] [PubMed]

6. Gao, H.M.; Wang, Z. Triterpenoid saponins and phenylethanoid glycosides from stem of Akebia trifoliata var. australis. Phytochemistry 2006, 67, 2697-2705. [CrossRef] [PubMed] 
7. Iwanaga, S.; Warashina, T.; Miyase, T. Triterpene saponins from the pericarps of Akebia trifoliata. Chem. Pharm. Bull. 2012, 60, 1264-1274. [CrossRef] [PubMed]

8. Wang, Y.; Lu, J.; Lin, R.C. The chemical constituents from the stem of Akebia trifoliata. Chin. Tradit. Herb. Drugs 2004, 35, 495-498.

9. Guan, S.G.; Yu, W.B.; Guan, S.H. The phenolic acid and phenoglycoside of Akebia trifoliata. Lishizhen Med. Mater. Med. Res. 2010, 21, 905-906.

10. Guan, S.H.; Xia, J.M.; Lu, Z.Q.; Chen, G.T.; Jiang, B.H.; Liu, X.; Guo, D.A. Structure elucidation and NMR spectral assignments of three new lignan glycosides from Akebia trifoliata. Magn. Reson. Chem. 2008, 46, 186-190. [CrossRef] [PubMed]

11. Wang, J.; Ren, H.; Xu, Q.L.; Zhou, Z.Y.; Wu, P.; Wei, X.Y.; Cao, Y.; Chen, X.X.; Tan, J.W. Antibacterial oleanane-type triterpenoids from pericarps of Akebia trifoliata. Food Chem. 2015, 168, 623-629. [CrossRef] [PubMed]

12. Luo, J.G.; Ma, L.; Kong, L.Y. New triterpenoid saponins with strong a-glucosidase inhibitory activity from the roots of Gypsophila oldhamiana. Bioorg. Med. Chem. 2008, 16, 2912-2920. [CrossRef] [PubMed]

13. Wang, D.; Zhou, G.P.; Yang, Y.S.; Su, Y.L.; Ji, T.F. A new bidesmoside triterpenoid saponin from Stauntonia chinensis. Chin. Chem. Lett. 2009, 20, 833-835. [CrossRef]

14. Wang, J.; Xu, Q.L.; Zheng, M.F.; Ren, H.; Lei, T.; Wu, P.; Zhou, Z.Y.; Wei, X.Y.; Tan, J.W. Bioactive 30-Noroleanane triterpenes from the pericarps of Akebia trifoliata. Molecules 2014, 19, 4301-4312. [CrossRef] [PubMed]

15. Gui, M.Y.; Jin, Y.R.; Wang, B.Z. Chemical constituents of Rabdosia japonica. Chin. J. Pharm. 1999, 34, 516-518.

16. Ieyama, T.; Gunawan-Puteri, M.D.; Kawabata, J. $\alpha$-Glucosidase inhibitors from the bulb of Eleutherine americana. Food Chem. 2011, 128, 308-311. [CrossRef] [PubMed]

17. Xu, X.Y.; Xie, H.H.; Hao, J.; Jiang, Y.M.; Wei, X.Y. Eudesmane sesquiterpene glucosides from lychee seed and their cytotoxic activity. Food Chem. 2010, 123, 1123-1126. [CrossRef]

18. Feng, J.; Yang, X.W.; Wang, R.F. Bio-assay guided isolation and identification of $\alpha$-glucosidase inhibitors from the leaves of Aquilaria sinensis. Phytochemistry 2011, 72, 242-247. [CrossRef] [PubMed]

19. Li, W.; Fu, H.W.; Bai, H.; Sasaki, T.; Kato, H.; Koike, K. Triterpenoid saponins from Rubus ellipticus var. obcordatus. J. Nat. Prod. 2009, 72, 1755-1760. [CrossRef] [PubMed]

Sample Availability: Samples of the compounds 1-7 are available from the authors.

(C) 2016 by the authors; licensee MDPI, Basel, Switzerland. This article is an open access article distributed under the terms and conditions of the Creative Commons Attribution (CC-BY) license (http:/ / creativecommons.org/licenses/by/4.0/). 